\title{
Analisis Faktor Risiko Kejadian Perdarahan Post Partum pada Ibu Hamil Anemia di Puskesmas Karang Duren Kabupaten Jember Selama Tahun 2012-2016
}

\author{
Fikhy Rizky H ${ }^{1}$, Arisanty Nursetia Restuti ${ }^{2}$, Rossalina Adi Wijaya ${ }^{2}$, \\ Adhiningsih Yulianti \\ Puskesmas Karang Duren ${ }^{1}$ \\ Jurusan Kesehatan, Politeknik Negeri Jember, Indonesia ${ }^{2}$ \\ e-mail: rossa@polije.ac.id
}

\begin{abstract}
Factors that influence the incidence of postpartum hemorrhage are prolonged labor, parity, excessive stretching of the uterus, drip oxytocin, anemia, and labor with action. Pregnant women who have anemia $(\mathrm{Hb}<11 \mathrm{gr} / \mathrm{dl})$ will quickly be disrupted if there is little blood loss during labor. This study aims to determine the magnitude of risk factors for the occurrence of post partum hemorrhage in anemic pregnant women at the Karang Duren Health Center in Jember Regency during 2012 - 2016. The research was conducted during January - May 2017 in the working area of the Karang Duren Puskesmas. This research method is an analytic observational method with a retrospective approach. The subjects were 94 pregnant women divided into 5 villages in the Karang Duren Subdistrict, Jember Regency. The technique of taking the subject uses proportional random sampling. The variables in this study were anemia status (independent) and the incidence of postpartum hemorrhage (dependent). This study processes secondary data held by Karang Duren Public Health Center in Jember Regency during 2012-2016. Statistical analysis uses Chi-square test. The results showed that postpartum hemorrhage was more common in subjects with anemia (80.43\%), whereas subjects without anemia experienced less postpartum hemorrhage (19.57\%). There is a relationship between anemia status in pregnant women with the incidence of post partum hemorrhage, this is indicated by the value of $p$ value $=0.005$. Analysis of the risk of post partum hemorrhage in pregnant women with anemia status $15.62 x$ greater than in pregnant women without anemia.
\end{abstract}

Keywords: anemia, pregnant women, post partum hemorrhage.

\section{Pendahuluan}

Anemia pada ibu hamil saat ini masih merupakan salah satu masalah utama kesehatan masyarakat di Indonesia (Laksana et al, 2012; Kemenkes RI, 2013a).
Anemia defisiensi besi (ADB) merupakan anemia yang paling sering dijumpai dan terjadi pada sepertiga penduduk dunia, terutama di negara - negara tropik dan atau negara dunia ketiga 
(Bakta et al, 2006). Anemia adalah suatu keadaan yang ditandai oleh penurunan kadar hemoglobin $(\mathrm{Hb})$ darah dibawah normal (Arisman, 2009).

Anemia secara umum dapat disebabkan oleh gangguan pembentukan eritrosit dalam sumsum tulang, kehilangan darah kronis akibat perdarahan akut atau kronis dan proses penghancuran eritrosit dalam tubuh sebelum waktunya (hemolisis) (Bakta, 2006). Gangguan pembentukan eritrosit dalam sumsum tulang dapat disebabkan oleh kurangnya bahan essensial pembentuk eritrosit seperti besi, asam folat $\begin{array}{lll}\text { atau vitamin } & \text { B } & 12\end{array}$ (Sulistyoningsih, 2011).

Perdarahan postpartum adalah perdarahan lebih dari 500 cc yang terjadi setelah bayi lahir pervaginam atau lebih dari 1000 cc setelah persalinan abdominal dalam 24 jam dan sebelum 6 minggu setelah persalinan. Adapun faktor-faktor yang mempengaruhi kejadian perdarahan post partum adalah partus lama, paritas, peregangan uterus yang berlebihan, oksitosin drip, anemia, dan persalinan dengan tindakan Ibu hamil yang mengalami anemia $(\mathrm{Hb}<11$ gr/dl) akan dengan cepat terganggu kondisinya bila terjadi kehilangan darah saat persalinan meskipun hanya sedikit. Anemia dapat disebut sebagai penyebab langsung perdarahan post partum (Ediyanti, 2014). Penelitian ini secara umum bertujuan mengetahui besarnya faktor risiko kejadian perdarahan post partum pada ibu hamil anemia di Puskesmas Karang Duren Kabupaten Jember selama tahun $2012-2016$.

\section{Metode}

Jenis penelitian ini adalah observasional analitik dengan pendekatan retrospektif. Variabel dalam penelitian ini adalah status anemia (independen) dan kejadian perdarahan post partum (dependen). Lokasi penelitian adalah wilayah Puskesmas Karang Duren dengan waktu pelaksanaan bulan Januari-Mei 2017. Populasi dalam penelitian ini adalah ibu hamil. Subjek penelitian berjumlah 94 ibu hamil terbagi dalam 5 desa di wilayah Kecamatan Karang Duren Kabupaten Jember.

\subsection{Metode Pengumpulan Data}

Teknik pengambilan subjek menggunakan propotional random sampling. Analisis faktor risiko kejadian perdarahan post partum pada ibu hamil anemia diketahui dengan melakukan uji hubungan dengan bantuan software pengolahan data.

\subsection{Metode Analisis Data}

Penelitian ini mengolah data sekunder yang dimiliki Puskesmas Karang Duren Kabupaten Jember selama Tahun 2012-2016. Selanjutnya dilakukan 
perhitungan odds ratio untuk menghitung faktor risiko kejadian perdarahan post partum pada ibu hamil dengan status anemia.

\section{Hasil dan Pembahasan}

\subsection{Karakteristik Subjek}

1) Distribusi Status Anemia Anemia kehamilan ditemukan pada $46 \quad(48,94 \%)$ subjek, sedangkan yang tidak mengalami anemia kehamilan sebanyak 48 (51,06\%) subjek.

Tabel 1. Distribusi Status Anemia

\begin{tabular}{lcc}
\hline \multicolumn{1}{c}{$\begin{array}{c}\text { Status } \\
\text { Anemia }\end{array}$} & n & $\begin{array}{c}\text { Prosentase } \\
(\%)\end{array}$ \\
\hline Anemia & 46 & 48,94 \\
Tidak Anemia & 48 & 51,06 \\
Total & 94 & 100 \\
\hline
\end{tabular}

Di Indonesia prevalensi ADB pada ibu hamil masih cukup tinggi yaitu mencapai $36,4 \%$ di daerah perkotaan dan $37.8 \%$ di daerah pedesaan (Kemenkes RI, 2013b).

\section{2) Distribusi Status Perdarahan Postpartum}

Subjek yang mengalami perdarahan post partum frekuensinya sama dengan yang tidak mengalami perdarahan postpartum.

Faktor risiko perdarahan Post Partum dapat ada saat sebelum kehamilan, saat kehamilan, dan saat persalinan. Faktor risiko sebelum kehamilan meliputi usia, indeks massa tubuh, kadar $\mathrm{Hb}$ dan riwayat perdarahan postpartum. Faktor risiko selama kehamilan meliputi usia, indeks massa tubuh, riwayat perdarahan postpartum, kehamilan ganda, plasenta previa, preeklampsia, dan penggunaan antibiotik. Sedangkan untuk faktor risiko saat persalinan meliputi plasenta previa anterior, plasenta previa mayor, peningkatan suhu tubuh $>37^{\circ}$, korioamnionitis, dan retensio plasenta (Briley et al., 2014).

Tabel 2. Distribusi Status Perdarahan Postpartum

\begin{tabular}{lcc}
\hline \multicolumn{1}{c}{ Status } \\
$\begin{array}{l}\text { Perdarahan } \\
\text { Postpartum }\end{array}$ & n & $\begin{array}{c}\text { Prosentase } \\
(\%)\end{array}$ \\
\hline $\begin{array}{l}\text { Peradarahan } \\
\text { Postpartum } \\
\text { Tidak }\end{array}$ & 47 & 50 \\
$\begin{array}{l}\text { Perdarahan } \\
\text { Postpartum } \\
\text { Total }\end{array}$ & 47 & 50 \\
\hline
\end{tabular}

\subsection{Faktor Risiko Kejadian Perdarahan Post Partum Pada Ibu Hamil Anemia}

Perdarahan post partum lebih banyak didapatkan pada subjek yang mengalami anemia $(80,43 \%)$, sedangkan subjek yang tidak anemia lebih sedikit mengalami perdarahan post partum $(19,57 \%)$.

Tabel 3. Kejadian Perdarahan Post partum pada ibu hamil anemia

\begin{tabular}{cccc}
\hline \multirow{2}{*}{ Status anemia } & \multicolumn{2}{c}{$\begin{array}{c}\text { Perdarahan } \\
\text { Post Partum }\end{array}$} & \multirow{2}{*}{ Total } \\
\cline { 2 - 3 } & Ya & Tidak & \\
\hline Anemia & 37 & 9 & 46 \\
Tidak anemia & 10 & 38 & 48
\end{tabular}




\begin{tabular}{cccc}
\hline \multirow{2}{*}{ Status anemia } & \multicolumn{2}{c}{$\begin{array}{c}\text { Perdarahan } \\
\text { Post Partum }\end{array}$} & \multirow{2}{*}{ Total } \\
\cline { 2 - 3 } & Ya & Tidak & \\
\hline Anemia & 37 & 9 & 46 \\
Tidak anemia & 10 & 38 & 48 \\
Total & 47 & 47 & 94 \\
\hline
\end{tabular}

Analisis faktor risiko kejadian perdarahan post partum pada ibu hamil anemia dapat diketahui dengan melakukan uji hubungan dengan menggunakan uji chisquare. Berdasarkan hasil uji dapat diketahui bahwa terdapat hubungan antara status anemia pada ibu hamil dengan kejadian perdarahan post partum, hal ini ditunjukkan dengan nilai $p=$ $0,000 \quad(\mathrm{p}<0,05)$. Penelitian ini sejalan dengan penelitian Frass (2015) yang melaporkan bahwa terdapat hubungan antara anemia dengan risiko perdarahan postpartum. Anemia pada kehamilan menyebabkan oksigen yang diikat dalam darah kurang sehingga jumlah oksigen berkurang dalam uterus dan menyebabkan otot-otot uterus tidak berkontraksi dengan adekuat sehingga menimbulkan perdarahan postpartum. Penelitian lain dengan judul Faktor Faktor yang mempengaruhi Perdarahan Post Partum menemukan bahwa terdapat hubungan perdarahan postpartum dengan yaitu paritas $(b$-value $=0,042, \quad \mathrm{OR}=0,351)$, oksitosin drip ( $p$-value $=0,002$, $\mathrm{OR}=8,222)$ dan anemia ( $p$-value
$=0,016$, $\mathrm{OR}=4,846$ )

(Satriyandari, 2017).

Faktor risiko kejadian perdarahan post partum pada ibu hamil anemia diketahui dengan melakukan perhitungan odds ratio yang menunjukkan hasil 15,62. Artinya, risiko kejadian perdarahan post partum pada ibu hamil dengan status anemia 15.62 $\mathrm{x}$ lebih besar dari pada ibu hamil yang tidak anemia

\section{Kesimpulan}

\subsection{Kesimpulan}

Berdasarkan hasil dan pembahasan dari penelitian mengenai analisa besarnya faktor risiko kejadian perdarahan post partum pada ibu hamil anemia di Puskesmas Karang Duren Kabupaten Jember selama tahun 2012 - 2016 dapat ditarik kesimpulan sebagai berikut :

1. Angka Kejadian anemia pada ibu hamil adalah 48,94\%

2. Angka Perdarahan Post Parum adalah $50 \%$

3. Angka Perdarahan postpartum pada bu hamil anemia $80,43 \%$

4. Risiko kejadian perdarahan post partum pada ibu hamil dengan status anemia $15.62 \mathrm{x}$ lebih besar dari pada ibu hamil yang tidak anemia.

\subsection{Saran}

Diperlukan penelitian lanjut dengan faktor lain yang mempengaruhi kejadian postpartum selain anemia seperti tekanan darah, pengetahuan, 
status gizi, asupan zat gizi dan lain sebagainya. Penelitian lanjut dengan menggunakan desain penelitian cohort.

\section{Daftar Pustaka}

Arisman. (2009). Gizi dalam Daur Kehidupan edisi 2. Jakarta: EGC.

Bakta, I M, Suega K, Tjokorda G D. (2006). Anemia Defisiensi Besi. Halaman 634 - 640. Editor Aru W S, Bambang S, Idrus A, Marcelinus S K, Siti S. Buku ajar Ilmu Penyakit Dalam. Jilid II Edisi IV. Pusat Penerbitan Ilmu Penyakit Dalam Fakultas Kedokteran Universitas Indonesia. Jakarta.

Bakta, I M. (2006). Pendekatan terhadap pasien anemia. Halaman 622 - 626. Editor Aru W S, Bambang S H, Idrus A, Marcelinus S K, Siti S. Buku ajar Ilmu Penyakit Dalam. Jilid II Edisi IV. Pusat Penerbitan Ilmu Penyakit Dalam Fakultas Kedokteran Universitas Indonesia. Jakarta.

Edyanti, DB dan Rachmah I. (2014). Faktor Pada Ibu yang Berhubungan dengan Kejadian Komplikasi
Kebidanan. Jurnal Biometrika dan Kependudukan. Vol. 3, No. 1 Juli 2014: 1-7. Surabaya.

Kementerian Kesehatan Republik Indonesia. (2013). Riset Kesehatan Dasar 2013. Jakarta. Badan Penelitian dan Pengembangan Kesehatan Kementerian Kesehatan Republik Indonesia.. 2013b. Rencana Kerja Pembinaan Gizi Masyarakat 2013. Jakarta. Direktorat Gizi Direktorat Jenderal Bina Gizi dan KIA Kementerian Kesehatan RI.

Laksana, ASD, Widiastuti R, Krisnansari D, Soenarto. (2012). Efektivitas pemberian tablet besi terhadap anemia pada ibu hamil di puskesmas 1 kembaran kabupaten Banyumas. Halaman 1 - 8. Prosiding Seminar Nasional Kesehatan. Jurusan Kesehatan Masyarakat FKIK UNSOED. Purwokerto.

Sulistyoningsih, H. (2011). Gizi Untuk Kesehatan Ibu dan Anak. Edisi 1. Yogyakarta: Graha Ilmu. 